\title{
BCL6 Gene Amplification
}

National Cancer Institute

\section{Source}

National Cancer Institute. BCL6 Gene Amplification. NCI Thesaurus. Code C132022.

A molecular genetic abnormality indicating the presence of multiple copies of the BCL6 gene. 